\title{
Accessing Credit Finance by Artisanal Fishermen: The Case of Lake Victoria in Kisumu, Kenya
}

\author{
Richard O. Akuno Nyang'aya ${ }^{1}$, Oloo Jack Onyango ${ }^{2}$ \\ ${ }^{1,2}$ Department of Accounting, Finance and Management Science, Egerton University, P.O.BOX, 536, Egerton, 20115, Kenya
}

\begin{abstract}
The Fisheries sector contributes 1\% to the Gross domestic Product (GDP) of Kenya. Secondly, it employs at least 800,000 people directly and another 3 million people indirectly. Moreover, it provides income and a source of food security. However, there is a gap of $7.6 \mathrm{Kg} / \mathrm{capita}$ of fish in Kenya coupled with other constraints such as inadequate financing of artisanal fishermen. Therefore the objective of this study was to identify factors that impact on the access to financing by artisanal fishermen in Lake Victoria. A total of 314 artisanal fishermen were interviewed from landing beaches along Lake Victoria. A 5 point Likert scale was used to assess the awareness of the respondents on access to financing. Consequently a factorial analysis was used to order the factors that influence the access to financing. The order of factors that had an impact on access to credit finance were found to be: saving regulations (F1), group characteristics(F2), socio economic characteristics of fishermen(F3), gender issues(F4), household expenditures(F5) and marital status(F6). The results can be used in financial interventions since they show that the fishermen are aware of their preference in accessing finance.
\end{abstract}

Keywords: Credit Finance, Artisanal Fishermen, Lake Victoria

\section{Introduction}

The Fishing sector in Kenya contributes to the $0.5 \%$ to the GDP (Gross Domestic Product) and is ranked as the second highest sector in terms of income generation after the agriculture and forestry sector (Kenya National Beraue of Standards, 2012). Secondly fishing is a direct source of employment to at least 80,000 and another 800,000 indirectly along the fish value chain (Mwangi, 2008). These actors include the input suppliers, fishermen, traders, transporters and by product users of the fish industry in Kenya. The third role of the fishing industry is the provision of food to millions of Kenya (Daw et al., 2012). This function ensures that Kenyans are food secure and reduces the risk of malnutrition.

According to Defaux \& Hjort (2012) there is unsatisfied demand of $7.6 \mathrm{Kg} /$ capita of fish in Kenya. This growth in the fish industry has been attributed to the increased demand for fish by individuals in the peri urban centers. This demand has been attributed to increase preference for white meat due to quality, availability and taste of fish (Obiero et al., 2014). In addition white meat is perceived to have a lower cholesterol levels and hence suitable for the health conscious consumers. The Government of Kenya has also invested Ksh 1.2 billion in 1586 new fishponds, owned by 6328 farmers through the Economic stimulus programme (ESP) and Fish Farming enterprise productivity programme (FFEPP) of inland fish farming as an alternative to income generation by smallholder farmers (KNBS, 2010). These promotions have resulted in the increase in the number of fish ponds and increase in income from fish farming (Ondoro \& Omena, 2012).

Lake Victoria is a fresh water lake that is shared by 3 East Africa countries namely, Kenya (6\%), Uganda (42\%) and Tanzania (52\%) (Daw et al., 2012). Secondly, Lake Victoria produces $75.9 \%$ of the fresh water fish in Kenya, which is estimated at 122,835 tonnes of fish (Defaux \& Hjort, 2012).
On the other hand, coastal fishing accounts for $6 \%$ of the fish production in Kenya (Manch et al.,2015). The scale of fishing varies depending on the level of capital and management practices done by the fishermen (Mbaru, 2012). There is however $65 \%$ of the population around Lake Victoria that lives below the poverty line. Fishermen groups and societies provide some leverage to the fishermen who may not be able to access sufficient capital for fishing (Osondu, 2014). The fishermen groups require capital for the purchase of boats, fishing equipments and payment of labourers (Charo-karisa et al., 2014). The lack of capital leads to improvising by the fishermen which usually result into inefficiencies and losses in some cases (Oloo, 2011). These fishermen faced export bans in 1997, 1998 and 1999, which lead to as low as only $6 \%$ of the Lake Victoria fish being exported to Europe (Maina, 2011). These restrictions lead to seasonality in the operation of the fishermen that cause low yields and loss of potential income.

Ardjosoediro \& Neven,( 2008) analysed the fishing value chain in Kenya and reported that traders offered credit at an interest rate of $10 \%$ to fish mongers. This study found that trade credit was wide spread but artisanal fishermen used the informal sources as the banks were costly and required travel over long distance. On the other hand the large scale fishermen were well financed and offered credit to the artisanal fishermen at the beaches. The credit services were also offered by processing companies to assist the artisanal fishermen. It was also noted that most of the artisanal fishermen were not financial literate and had a low saving level. In addition some financial institutions offered credit at an interest rate of $1.5 \%$ per month. Commercial banks offer loans at a lower cost. There are institutions such as saving and credit cooperative societies (SACCOS), Accumulated savings and credit societies (ASCAS) are used for channeling credit to the groups. There are innovative credit facilities that have been set up by banks and financial institutions along the beaches. 


\section{International Journal of Science and Research (IJSR) \\ ISSN (Online): 2319-7064}

Index Copernicus Value (2013): 6.14 | Impact Factor (2015): 6.391

\section{Literature Review}

The following section reviews literature that is related to access of credit in aquaculture and the factors that affect the access of credit by small scale fish farmers. The review shows the gaps that the current study aimed at filling.

\subsection{Access to credit finance in aquaculture}

Access to credit by artisanal fishermen has been analysed in different studies. (Okwu,et al., 2011) analysed the information needs of artisanal fishermen in Nigeria and reported that there was limited information related to the access of credit by artisanal fishermen. Therefore they recommended improved extension services to artisanal fishermen to enable them access more information related to credit access. A study by (Mwaijande \&Lugendo, 2013)found that $49 \%$ of the surveyed fishermen in Tanzania were constrained in access to credit or loans and resulted in using their own funds for fish farming. In addition the study found that few of the artisanal fishermen were able to access loans from financial institutions.

Opondo (2011) analysed the fishermen and the trade in Lake Victoria in relation to the colonial policy. The analyses showed that the colonial government had introduced credit facilities but were not improved by successive governments. Further this study by Opondo (2011) suggested that there would be an increased production once credit was accessed by artisanal fishermen. However initial credit provision was skewed to favour the white settlers and farmers, which disadvantage the native fishermen. The study highlighted the lack of access to credit as a hindrance in the development of fisheries in Kenya during the colonial and post-colonial periods.

Fish farming has been examined as a means of improving the livelihoods of fishermen in Lake Victoria, Kenya. A study by (Jacobi \& Colombi, 2013) showed that the Lake Basin Development Authority (LBDA) was the only agency that provided credit facilities to farmers that were organised in groups. In addition the Government of Kenya offered credit for fish farming through Agricultural Finance Corporation (AFC).However the number of artisanal fishermen that use credit still was low despite the demand of fish in the international markets (Defaux \& Hjort,).

Ruddle (2011) assessed the informal credit schemes in fishing communities in Vietnam. The credit was organised formally and informally then used to finance the purchase of boats and operations of the fishermen. This credit was obtained from banks, family members, friends and money lenders. The stringent lending conditions and high interest rates in the informal credit sector made it unattractive for artisanal fishermen. The rate of obtaining credit from family members ranged between 20 to $55 \%$. Further the level of credit was between 100 to $300 \%$ of the annual profits.

Thompson \& Mafimisebi (2014) reported that over 87\% did not have any access to credit among the catfish aquaculture in Nigeria. Olaoye et al., (2013) found that the lack of groups among artisanal fishermen affected the access to credit and information by fishermen. However $63.5 \%$ of the respondents did not consider the lack of credit as a hindrance to the development of fisheries.

Jentoft \& Onyango (2010) assessed artisanal fisheries in Bangladesh and Tanzania. The study showed that artisanal fishermen were constrained in the access of credit due to the lack of collateral and landed assets. Consequently fishermen relied on informal credit systems e.g. Dandon, which lead them to sell fish at prices that were $20-40 \%$ lower than the market prices. This caused the dandodar to be the owner of the family assets and fish. In addition the uncertain income of the fishermen caused difficulties in repayment of the loans from micro creditors.

Oloo (2011) conducted a survey on the influence of fish farming on the economy of Kisumu in Kenya. Access to credit for fish farming was found to be a major constraint for fishermen who were not cooperative members. The cooperative members on the other hand were able to repay loans and had alternative sources of income. There was however non cash credit organized among the traders, when obtaining fish stocks.

Kariuki (2011) reported that fish traders in different outlets in Kenya use informal sources of credit. A total of $50 \%$ of the traders used "merry go rounds", 17\% used family and friends, while $21 \%$ used financial institutions and formal banks to access credit for their operations. The credit was used for purchase of fish stock, equipments and to facilitate daily operations.

\subsection{The determinants of accessing credit in aquaculture}

(Olale \& Henson, 2013) assessed the income diversification among the fishermen in Western Kenya. The results of the study showed that access to credit, education level and membership in associations were key determinants of the diversification of income among the fishermen in Western Kenya. Osondu (2014) reported that there was a significant association between access to credit and production among the fishermen in Nigeria. There were $63.9 \%$ of the farmers in the study without access to credit. Despite the low access to credit the fish farming had a benefit cost ratio (BCR) of 2.20 and RORCI of $90 \%$.

Acquah \& Abunyuwah (2011) established a significant relationship between access to credit and the decision to become a fisherman in Ghana. On the other hand the same study showed that respondents cited: lack of storage facilities $(57 \%)$, lack of credit (85\%), high transport costs $(45 \%)$, unpredictable weather conditions and low governance assistances were the main constraints in fish farming.

\subsection{Conceptual Framework}

The three main finance theories applicable to this study are Utility Theory, Trade-off Theory and Pecking Order Theory. The Utility Theory was advanced by Fishburn in the 1968 (Fishburn, 2010). The theory is used in selecting investments. In this theory, it is noted that decision makers can either be 


\section{International Journal of Science and Research (IJSR) \\ ISSN (Online): 2319-7064}

Index Copernicus Value (2013): 6.14 | Impact Factor (2015): 6.391

risk takers, risk averse or risk neutral individuals. One cannot be able to tell with certainty whether a decision maker will choose a project with high expected returns and a high standard deviation or a project with a comparatively low expected return and low standard deviation under this theory. It has been explained in the literature that most financial institutions are not willing to give loans to fishermen fearing the risk involved. Their decision is therefore that of a risk averse investor. To a risk averse investor the amount to be invested is a function of risk involved. Such risks to a fisherman are factors influencing access to financing. The theoretical model can be given as (Pike et al.,2012):

$\mathrm{I}=\mathrm{F}(\mathrm{R})$ or $\mathrm{C}=\mathrm{F}(\mathrm{CC})$, where: $\mathrm{I}$ refers to Credit amounts lent by investors/amounts of financing received, $\mathrm{R}$ refers to Default Risks and CC refers to Credit access constraints/factors influencing access to financing and $\mathrm{C}$ access to financing

The related curve under utility theory is shown in figure 1.1 below:

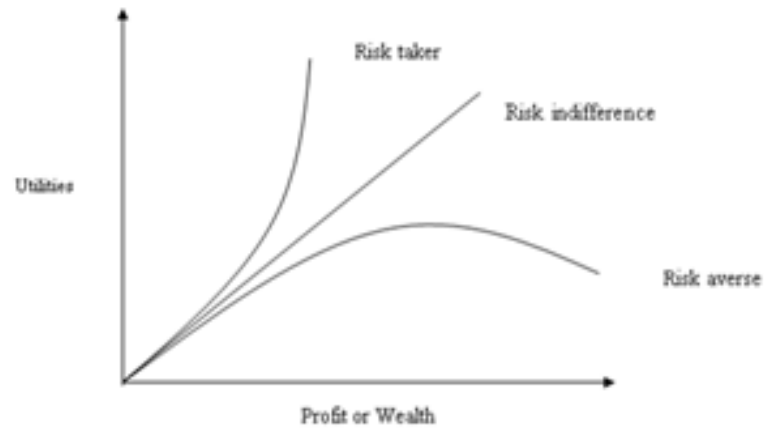

Figure 1: Risk Profile

Source-(Pike,et al., 2012)

In mathematical programming, we can derive the objective function of optimizing borrowing costs as: MinimizeInterest and fees paid to the lender and Maximizeopportunity costs of compensating balances. The Trade-off Theory recognizes that firms seek to exploit the lower cost benefits of borrowing especially the tax shield (Frank \& Goyal, 2007). At the same time the firms are reluctant to increase the financial risks entailed in entering contractual commitments to make ongoing interest and capital repayments. The firms trade- off returns against the risks. The firms enjoying higher and more stable profit level can operate at higher borrowing levels. The smallholder fishermen due to their earning levels can operate only at lower borrowing levels in order to avoid risks. According to this theory the relationship between borrowing risks and returns can be expressed as;

$\mathrm{B}=\mathrm{kR}$ Where: $\mathrm{B}$ refers to The risks of borrowing, $\mathrm{R}$ refers to Returns, earnings or profits and refers to Constant or other factors

The Pecking Order Theory suggests that firms or borrowers have an order of priorities in selecting among alternative forms of finance (Franz and Goyal, 2007). Firms first, prefer the use of internal finance generated by operating cash flows. Second, they prefer to borrow when internal sources are drained and third they regard selling new shares almost as a last resort. According to (Pike et al., 2012), this order of preference lies in information asymmetry in that managers know far more about the firms performance and prospects than outsiders and are more inclined to issue shares when they believe the shares are overvalued.

Fishermen would rather use their internally generated funds rather than borrowed funds due to difficulties in accessing external financing as explained by the Pecking Order Theory (Frank \&Goyal, 2007). Since internal financing is regarded as the cheapest source of finance and the theory gives the order of preference starting with internally generated funds. It implies that financing is a function of costs. An increase in financing implies decrease in costs. This can be illustrated using the following mathematical model: $F=f(C)$ and $F=$ 1/C Where: $\mathrm{F}$ - Amounts of funds accessed by the fishermen and $\mathrm{C}-$ Costs of financing.

There are socio-demographic factors such as Gender, Age, Marital Status, Experience, and Education which influence access to financing (Kumar et al., 2008). Other factors such as Location, Awareness, Membership of a Cooperative Society or Loan Groups, Cost of Finance, Collateral, Fishing Income, Expenditure on social satisfaction and Household Role, Savings and Other Sources of Income also influence access to financing. The following diagram (Figure 2) represents the framework

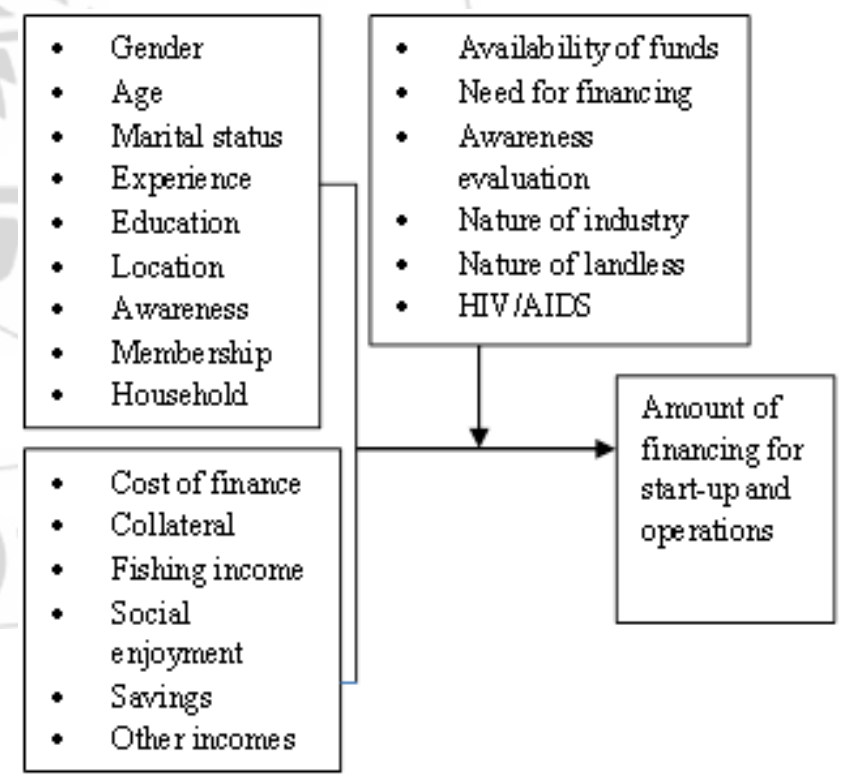

Figure 2: Conceptual Framework

All forms of financings are inputs into fishery activities. If the factors limiting access to financing are eliminated, it is hoped that the funds will be available for use by fishermen in fishing activities. Proper use of these funds for example in purchasing the more efficient fishing equipment will result into greater harvesting. The fishermen will therefore earn more from the sale of their catch. Part of this earning can be reinvested for a further increased income from fishing (Matiya \& Wakabayashi, 2005) 


\section{International Journal of Science and Research (IJSR) \\ ISSN (Online): 2319-7064}

Index Copernicus Value (2013): 6.14 | Impact Factor (2015): 6.391

\section{Research Methodology}

This section discusses the methods that were used in the collection and analysis of data for the study.

\subsection{Area of Study}

Lake Victoria has an estimated area of $184,200 \mathrm{Km}^{2}$ and is surrounded by 5 countries namely: Kenya, Burundi, Tanzania, Uganda and Burundi. The distribution of the percentage of the water surface that is found in 3 countries are Kenya (6\%), Tanzania (49\%) and Uganda (45\%) (The World Agro forestry Center (WAFC, 2006). The altitude of the Lake Victoria Basin ranges from 1135 meters above sea level to 4,000 m.a.s.l at the Mt Longonot peak (Raburu, 2012).

The population of the lake basin is estimated at 35 million people (Drankensberg et al., 2007 in Maina, 2012). There are many economic activities including fisheries, mining, tourism, farming among others that are carried out in the Lake basin. However, the poverty rates around the Lake Basin are still high at $60-65 \%$ US\$/day. The study was carried along Lake Victoria, Kenya in the districts of Busia, Bondo, Kisumu, Nyando, Rachuonyo, Suba and Migori where fishing is practiced. It covered the landing beaches in the districts.

\subsection{Research Design}

The research design used was descriptive survey design. The design required collection of quantifiable information from the fishermen (Kothari, 2004). Both quantitative and qualitative data were used in the survey. It involved collecting information relating to factors influencing access to financing from representative groups and comparing with amounts finances obtained by fishermen. Since fishery activities along Lake Victoria is organised into beaches, groupings into beaches was considered before the actual collection of data from the fishermen was done.

The research targeted the smallholder fishermen in Lake Victoria, Kenya numbering 10941 . The population ideally included the crew members. The fishermen are organised into landing beaches managed by Beach Management Units (BMUs). There are 265 landing beaches with an average of 10 boats. Each boat has an average of 4 crew members per one expedition.

\subsection{Sampling}

The sampling methods used were cluster sampling and systematic random sampling procedures. This method was appropriate for the population which was very large and scattered over a wide geographical area (Barreiro \& Albandoz, 2001). The method involved random selection of 10 beaches. All fishermen in the selected beaches were included in the sample for data collection. The 265 landing beaches were listed in a random order $1-265$ and sampled systematically from the $1^{\text {st }}$ landing beach and then every $26^{\text {th }}$ beach was included in order to obtain the 10 beaches required. The sampling technique used gave equal chances for every fisherman to be included in the study and was more reliable per unit cost (Kothari, 2004).

\subsection{Data Analysis}

The following section discusses factor analysis, which was used in the analysis of data in the present study.

\subsubsection{Factor analysis}

Factor analysis is a procedure that is used to extracts factors from an original set of data based on the proportion of their variance (Yong \& Pearce, 2013).Factor analysis also investigates the underlying relationship between variables $\mathrm{Y}_{1}, \mathrm{Y}_{2}, \mathrm{Y}_{3} \ldots \ldots \mathrm{Y}_{1}$ and unobservable factors $\mathrm{F}_{1}, \mathrm{~F}_{2}, \mathrm{~F}_{3} \ldots \ldots \mathrm{Fk}$ (Tryfos, 2001).The two types of factor analysis that are commonly used in data reduction are exploratory factor analysis(CFA) and confirmatory analysis(CFA) (Decoster \& Hall, 1998).

According to Yong \& Pearce (2013), two variables in a factor should not be correlated to other factors. A factor should have at least 3 variables depending on the design. The variables can be expressed as a function of the underlying factors and therefore these results into the following functions:

$\mathrm{Yi}=\beta+\beta 10 \mathrm{~F}+\beta \mathrm{F}+\beta \mathrm{F}+\beta \mathrm{F}+\mathrm{e}_{1}$

$\mathrm{Xj}=\mathrm{a}_{\mathrm{j} 1} \mathrm{~F}_{1}+\mathrm{aj} 2 \mathrm{~F}_{2}+\ldots \ldots \ldots+\mathrm{a}_{j m} \mathrm{~F}_{\mathrm{m}}+\mathrm{e}_{\mathrm{j}}, \ldots \ldots \ldots \ldots \ldots \ldots \ldots \ldots \ldots(2)$

where $j=1,2 \ldots \ldots \ldots . . p$ and $a_{j 1}, a_{j 2} \ldots a_{j m}$ are the factor loadings. The specific or unique factor is shown by $e_{j}$, while aj 1 indicates $\mathrm{jth}$ variable loads on the $1^{\text {st }}$ factor (Yong and Pearce, 2013).

According to Tryfos (2001), the error term e shows that some of the variation is not explained by the variables; hence the hypothesized relationships are not exact. Further the error terms are assumed to be independent of one another and such that $\mathrm{E}$ (ei) $=0$ and $\operatorname{var}(\mathrm{ei})=\mathrm{\sigma}_{\mathrm{i}}^{2}$ The parameter $\beta_{\mathrm{ij}}$ are referred to us loadings. The unobservable factors $F_{i}$ are independent of each other and their error terms such that $\mathrm{E}\left(\mathrm{F}_{\mathrm{j}}\right)=0$ and var $\left(F_{j}\right)=1$.The relationships explained constitute the common factor model (Decoster \& Hall, 1998).According to Decoster \& Hall (1998), the seven basic steps that are involved in the exploratory factor analysis (EFA) include: Collection of measurements, Production of the correlation matrix, Selection of number of factors for inclusion based on Kaiser Criterion and the scree plot. The selection of factors is based on eigenvalue greater than 1 , but this factors can be confirmed using the screen test and parallel analysis (Costello \& Osborne, 2005).

\section{Results and Discussion}

\subsection{Demographic characteristics of households}

The results of the household characteristics of the fishermen are presented in the Table 1.These includes the gender, age, marital status, experience in fishing, schooling levels and the location of the households. The average age of the household head was 35 years. Secondly, the average experience was 13.7 years and households were located an average of 10.6 $\mathrm{Km}$ from the households. 


\section{International Journal of Science and Research (IJSR) \\ ISSN (Online): 2319-7064 \\ Index Copernicus Value (2013): 6.14 | Impact Factor (2015): 6.391}

Table 1: Demographic characteristics of households

\begin{tabular}{|c|c|c|c|c|}
\hline Variable & Mean & Std. Dev. & Min & Max \\
\hline Age (years) & 35.24204 & 13.54647 & 14 & 83 \\
\hline Experience (years) & 13.74204 & 10.59419 & 1 & 60 \\
\hline Location to finance (Km) & 10.66242 & 6.943914 & 1 & 25 \\
\hline
\end{tabular}

Source: Research data(2012) $n=314$

\section{2: Socio economic characteristics of fishermen}

The majority of the household heads $(89 \%)$ was male and married $(82 \%)$, moreover most of them had completed secondary school (Table 2).

Table 2: Socio economic characteristics of fishermen

\begin{tabular}{|c|c|c|c|c|c|}
\hline Sex of house hold head & Frequency & Percentage & Education level & Frequency & Percentage \\
\hline Male & 278 & 89 & No schooling & 6 & 2 \\
\hline Female & 36 & 11 & Lower primary & 37 & 12 \\
\hline Marital status & & & Full primary & 57 & 18 \\
\hline Yes & 257 & 82 & Secondary school not complete & 85 & 27 \\
\hline No & 57 & 18 & Full secondary & 122 & 39 \\
\hline Savings (Ksh.) & & & Post-secondary & 7 & 2 \\
\hline $1-1000$ & 95 & 30 & Weekly incomes(Ksh) & & \\
\hline $1001-2000$ & 43 & 14 & $1-6000$ & 215 & 69 \\
\hline $2001-3000$ & 30 & 10 & $6001-12000$ & 76 & 25 \\
\hline $3001-4000$ & 7 & 2 & $12001-18000$ & 11 & 3 \\
\hline $4001-5000$ & 9 & 3 & $18001-24000$ & 11 & 3 \\
\hline No Saving & 130 & 41 & Reasons for joining fishing & & \\
\hline Use of finance & & 2 & Family members & 94 & 30 \\
\hline Purchase of equipments & 213 & $68 \times 1$ & Food & 135 & 43 \\
\hline Daily operations & 31 & 10 & Friends & 69 & 22 \\
\hline Other uses & 69 & 22 & Others & 15 & 5 \\
\hline
\end{tabular}

\subsection{Access to finance by fishermen}

The findings show that $83 \%$ of the fishermen interviewed accessed funds when starting their operations while the remaining 17 $\%$ started fishing without any form of financing. Table 4.8 below shows the sources of start-up finance used by the fishermen.

Table 3: Fishermen and credit financing characteristics

\begin{tabular}{|c|c|c|c|c|c|c|}
\hline \multirow[t]{2}{*}{ Source of finance } & \multirow[t]{2}{*}{ Frequency } & \multirow[t]{2}{*}{$\%$} & \multicolumn{2}{|c|}{ Number of Cooperative societies or loans groups } & \multirow{2}{*}{$\begin{array}{c}\text { Frequency } \\
\mathbf{7 0}\end{array}$} & \multirow{2}{*}{$\begin{array}{l}\% \\
22 \\
\end{array}$} \\
\hline & & & & 1 & & \\
\hline Own capital or savings & 153 & 49 & + & $\mathrm{sec}$ & 53 & 17 \\
\hline Loan from friends or relatives & 57 & 18 & +2 & $e^{-12}$ & 41 & 13 \\
\hline Loan from cooperatives or groups & 27 & 9 & 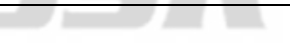 & 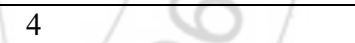 & 36 & 12 \\
\hline Loan from banks & 24 & 7 & 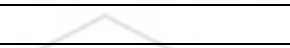 & 5 & 13 & 4 \\
\hline No financing & 53 & 17 & $x$ & 6 & 6 & 2 \\
\hline Total & 314 & 100 & No 1 & emberships & 95 & 30 \\
\hline Value of collateral and financing & Q & 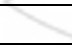 & Constraint to $r$ & ceiving credit finance & & \\
\hline $1-50000$ & $71 /$ & 23 & Uncertai & ty of repayment & 82 & 26 \\
\hline $50001-100000$ & 38 & 12 & $\mathrm{Lac}$ & of security & 54 & 17 \\
\hline $100001-150000$ & 32 & 10 & Shor & ge of funds & 9 & 3 \\
\hline $150001-200000$ & 20 & 6 & $\mathrm{Lc}$ & $N$ income & 20 & 6 \\
\hline $200001-250000$ & 16 & 5 & & saving & 13 & 4 \\
\hline $250001-300000$ & 5 & 2 & Non & nembership & 8 & 3 \\
\hline No collateral & 132 & 42 & Need & form groups & 8 & 3 \\
\hline & & & Have not be & 1 refused or applied & 120 & 38 \\
\hline
\end{tabular}

Source - Research Data (2012)

\subsection{Factors Influencing Access to Financing}

The results on Table 4 show the results of the factors influencing access to financing by fishermen. These results include the percentages in the response on the Likert scale, mean and the ranking of the individual responses. 


\section{International Journal of Science and Research (IJSR) \\ ISSN (Online): 2319-7064 \\ Index Copernicus Value (2013): 6.14 | Impact Factor (2015): 6.391}

Table 4: Factors Influencing Access to Financing

\begin{tabular}{|c|c|c|c|c|c|c|c|c|}
\hline & 1 & 2 & 3 & 4 & 5 & Total \% & $\begin{array}{c}\text { Mean } \\
\text { out of } 5\end{array}$ & Mode \\
\hline Gender is considered in accessing financing & 24 & 29 & 15 & 28 & 4 & 100 & 2.5 & 2 \\
\hline Age determine access to financing & 15 & 33 & 24 & 9 & 19 & 100 & 2.7 & 2 \\
\hline Marital status is considered by lenders & 38 & 28 & 10 & 8 & 16 & 100 & 2.1 & 1 \\
\hline Experience in fishing determine access to financing & 19 & 5 & 9 & 29 & 38 & 100 & 3.6 & 5 \\
\hline Education is important in accessing financing & 12 & 24 & 29 & 16 & 19 & 100 & 3.0 & 3 \\
\hline Nearness to a financial institution facilitate access to financing & 9 & 19 & 6 & 32 & 34 & 100 & 3.6 & 5 \\
\hline Fishermen are not informed about the various sources of financing & 14 & 24 & 17 & 28 & 17 & 100 & 2.9 & 4 \\
\hline Lenders consider membership in giving out funds & 6 & 18 & 13 & 28 & 38 & 100 & 3.7 & 5 \\
\hline Charges by lenders determine access to financing & 7 & 27 & 24 & 28 & 14 & 100 & 3.2 & 4 \\
\hline Lenders consider the value of collateral when giving out loans & 8 & 1 & 9 & 43 & 39 & 100 & 4.0 & 4 \\
\hline Lenders consider earnings from fishing when giving loans & 16 & 7 & 1 & 24 & 52 & 100 & 3.9 & 5 \\
\hline $\begin{array}{l}\text { Fishermen spend their earnings extravagantly } \\
\end{array}$ & 27 & 19 & 38 & 14 & 2 & 100 & 2.2 & 3 \\
\hline Household role compels a fisherman to seek financing for fishing activities & 19 & 10 & 24 & 27 & 20 & 100 & 3.2 & 4 \\
\hline Fishermen do not save part of their earnings & 5 & 43 & 8 & 19 & 25 & 100 & 3.1 & 2 \\
\hline Fishermen with other sources of income access more financing & 14 & 19 & 19 & 26 & 22 & 100 & 3.2 & 4 \\
\hline AVERAGE & 15 & 20 & 16 & 25 & 24 & 100 & 2.9 & 4 \\
\hline
\end{tabular}

\section{Source - Research Data (2012)}

\subsection{Components Matrix of Factors}

The results on Table 5 show the factors of the matrix and the loadings of the variables on each factor. The variables that with high loadings on factor 1 were savings (0.708) and collateral (0.599), therefore this factor can be labeled as savings regulations. Secondly the variables memberships (0.568) and experience (0.548) had the highest loadings on factor 2 and therefore this factor can be labeled group characteristics. Third the variables other incomes $(0.512)$ and gender $(0.393)$ had highest loadings on factor 3 ; therefore this factor can be labeled as socioeconomic characteristics. Fourth the variables gender (0.619) and social enjoyment (0.448) loaded highest on the factor 4, therefore it can be labeled as gender issues. Fifth the variables Education $(0.740)$ and social enjoyment loaded highest on the factor 5 , therefore this factor can be labeled as education expenditure. Finally the variable marital status (0.812) had the highest loading on the factor 6 ; therefore this factor can be labeled as marital status.

Table 5: Components Matrix of Factors

\begin{tabular}{|l|c|c|c|c|c|c|}
\hline & \multicolumn{7}{|c|}{ Component } \\
\hline & 1 & 2 & 3 & 4 & 5 & 6 \\
\hline Savings & .708 & -.029 & .050 & -.348 & .208 & .136 \\
\hline Location & -.648 & -.048 & -.058 & -.070 & .241 & .190 \\
\hline Collateral & .599 & -.330 & .374 & -.204 & -.075 & .158 \\
\hline Household role & .596 & -.066 & -.057 & -.481 & .045 & .024 \\
\hline Fishing Income & .534 & -.469 & -.422 & .145 & .085 & -.081 \\
\hline Awareness & .463 & .244 & -.113 & .074 & -.154 & -.433 \\
\hline Age & .420 & .218 & .378 & .282 & .314 & .117 \\
\hline Membership & .532 & .568 & -.260 & .067 & -.150 & .065 \\
\hline Cost & .272 & -.565 & -.177 & .216 & -.078 & -.067 \\
\hline Experience & .542 & .548 & -.349 & .117 & -.046 & .055 \\
\hline Other Incomes & .508 & -.183 & .512 & .054 & -.216 & .091 \\
\hline Gender & .105 & .120 & .393 & .619 & -.129 & -.138 \\
\hline Social enjoyment & .289 & -.424 & -.285 & .448 & .372 & .140 \\
\hline Education & .087 & .308 & .157 & -.018 & .740 & -.117 \\
\hline Marital status & .006 & .164 & -.112 & .166 & -.143 & .812 \\
\hline
\end{tabular}

Source - Research Data (2012)

The saving regulation is a factor that influences the access to finance by the fishermen (Table 5). The level of savings made by individual fishermen allowed them to have some start - up capital for purchasing fishing gears and to facilitate their daily operations. In addition most of the credit lenders require collaterals before offering any credit to fishermen. Mwajiande \& Lugendo (2015) showed that most financial institutions were cautious in extending credit to fishermen due to lack of collateral. Further collateral is a prerequisite for accessing capital for most fishermen (Jentoft \& Onyango, 2010). Moreover this may be the reason why most artisanal fishermen in Lake Victoria still do not access credit from despite the presence of many credit institutions in the area (Jacobi \& Colombi, 2013; Quagrainie, 2010).

The group characteristics were found to be an important factor in relation to the access of credit and finance by fishermen in Kisumu (Table 5).The groups are an important avenue of channeling finances by most financial institutions due to the presence of social capital. Further, the rate of default among the groups is low due to internal recovery mechanisms within groups. Olaoye et al., 2013 has shown that the absence of groups lead to difficulties in accessing credit among artisanal farmers. On the other hand the presences of fishermen groups facilitate easy operations and the purchase of equipments (Abila, 2015; Charo-karisa et al., 2014).

The socioeconomic factors were found to be an important factor in the access of finance by financial fishermen in Kisumu (Table 5).The socioeconomic characteristics of the households have an influence on the access to credit by the fishermen from different financial institutions in Kisumu. There are different studies (Olale \& Henson, 2013; Elizabeth, 2010) have shown a relationship between socioeconomic characteristics and access to credit and financing by fishermen.

\section{Conclusions and Recommendations}

\subsection{Conclusions}

The respondents in the study had an average age of 35 years and an average experience of 13.74 years in fishing. The households were located an average of $10.66 \mathrm{Km}$ from the 


\section{International Journal of Science and Research (IJSR) \\ ISSN (Online): 2319-7064}

Index Copernicus Value (2013): 6.14 | Impact Factor (2015): 6.391

financial institutions. Further, $89 \%$ of the respondents were male and $82 \%$ of them were also married, with most of them having a savings of between Ksh.1- Ksh.1000.On the other hand $69 \%$ of the respondents had a weekly income of between Ksh.1-Ksh.6, 000.The main reason for fishing was to get food according to $43 \%$ of the respondents and most of them $(68 \%)$ used finances to purchase fishing equipments.

The main source of capital was own savings according to $49 \%$ of the respondents. However $42 \%$ of them did not have collateral, while only $22 \%$ of the respondents were members of a group that offered loans. Further, most of the members had constraints in receiving credit from financial institutions.

According to the respondents' perception value of collateral $(4 / 5)$, consideration of earnings by financial institutions (3.9/5) and membership in groups (3.7/5) were ranked as the 3 important issues in accessing finance. On the other hand the factorial analysis showed that: - saving regulations, group characteristics, socio economic factors, gender issue, household expenditure and marital status have an impact on accessing finance.

\subsection{Recommendations}

Based on the factors identified from this study Government policies and stakeholders along the fish value chain in Lake Victoria should consider the following areas in their interventions: Women should be encouraged to participate actively in all aspects of the fishing occupation. Funds in form of credit facilities should be made available to women to purchase and own vessels and gears for use in primary fisheries. Financial institutions and the government should be involved in offering trainings, seminars, and exhibitions and shows to boost the fishermen's saving habits for enhanced cash flow and for improved financial management skills. Financial institutions should consider opening more branches along the lake and reducing collateral value in order to enhance fishermen's access to financing. The government should avail funds to the fishing communities through CDF, Youth Fund and Women Fund. These may be cheaper sources of financing for the fishermen. Researchers should advance studies on the factors above and how they affect financing of fishing operations.

\section{References}

[1] Abila, R. (2015). FISH SECTOR DEVELOPMENT STRATEGY FOR Kenya Fisheries Sub-Sector, (August).

[2] Acquah, H., \& Abunyuwah, I. (2011). Logit analysis of socio-economic factors influencing people to become fishermen in the central region of Ghana. Journal of Agricultural Sciences, Belgrade, 56(1), 55-64. http://doi.org/10.2298/JAS1101055A

[3] Ardjosoediro, I \& Neven, D. (2008). the Kenya Capture Fisheries Value Chain: an Amap-Fskg Value Chain Finance Case, (October), 1-50.

[4] Barreiro, P.L\&Albandoz, J. P. (2001). Population and sample. AJR. American Journal of Roentgenology, 177(5), 993-999.
[5] Charo-karisa, H., Munguti, J. M., Musa, S., Orina, P. S., Kyule, D. N., Opiyo, M. A., ... Ogello, E. O. (2014). An overview of current status of Kenyan fish feed industry and feed management practices, challenges and opportunities. International Journal of Fisheries and Aquatic Studies, 1(6), 128-137.

[6] Costello, a, \& Osborne, J. (2005). Best practices in exploratory factor analysis: Four recommendations for getting the most from your analysis. Practical Assessment, Research \& Evaluation, 10(7), 1-9.

[7] Daw, T. M., Cinner, J. E., McClanahan, T. R., Brown, K., Stead, S. M., Graham, N. a J., \& Maina, J. (2012). To Fish or not to Fish: Factors at multiple scales affecting artisanal fishers' readiness to exit a declining fishery. PLoS ONE, 7(2). http://doi.org/10.1371/journal.pone.0031460

[8] Decoster, J., \& Hall, G. P. (1998). Overview of Factor Analysis. In Practice, 37(2), 141 http://doi.org/10.2307/2685875

[9] Fishburn, P. C. (2010). UTILITY THEORY. Theories Series, 14(5), 335-378.

[10] Frank, M. Z., \& Goyal, V. K. (2007). Trade-Off and Pecking Order Theories of Debt. Handbook of Empirical Corporate Finance SET, 1, 135-202. http://doi.org/10.1016/B978-0-444-53265-7.50004-4

[11] Icraf. (2006). Improved land management in the Lake Victoria Basin: Final Report on the TransVic Project, 98.

[12] Jacobi, N., \& Colombi, A. B. J. (2013). Examining the Potential of Fish Farming to Improve the Livelihoods of Farmers in the Lake Victoria Region, Kenya Assessing Impacts of Governmental Support Athugun á möguleikum fiskeldis til að bæta lífskjör kenískra bænda við Viktoríuvatn - mat á áhrifum. Masters Thesis, (May).

[13] Jentoft, S., \& Onyango, P. (2010). Freedom and poverty in the fishery commons. International Journal of the Commons, 4(1), 345-366.

[14] Kariuki, M. B. J. (2011). Analysis of market performance:A case of "omena" fish in selected outlets in Kenya. A Thesis Submitted to the Graduate School in Partial Fulfillment for the Requirements of the Masters of Science Degree in Agricultural and Applied Economics of Egerton University, 75.

[15] KNBS. (2010). Economic Survey.

[16]Knbs. (2012). Kenya facts and figures 2012. Kenya National Bureau of Statistics, 78.

[17] Kothari, C. (2004). Research Methodology:Methods and Techniques(Second Revision Edition).

[18]Kumar, B. G., Datta, K. K., Joshi, P. K., Katiha, P. K., Suresh, R., Ravisankar, T., ... Menon, M. (2008). Domestic Fish Marketing in India-Changing Structure, Conduct, Performance and Policies. Agricultural Economics Research Review, 21(1984), 345-354. http://doi.org/hh

[19] Manach, F. Le, Abunge, C. A., Mcclanahan, T. R., \& Pauly, D. (2015). Tenatative reconstruction of Kenya's marine fisheries catch,1950-2010*. In Le Manach F and Pauly D(eds), 23(2), 37-52.

[20]Matiya, G \& Wakabayashi, Y. (2005). Small Scale Fisheries of Malawi: An Outline of Lake Malombe Fisheries. Mem.Fac.Agr.,Ehime Univ, (May), 3-5. 


\section{International Journal of Science and Research (IJSR) \\ ISSN (Online): 2319-7064}

Index Copernicus Value (2013): 6.14 | Impact Factor (2015): 6.391

[21] Mbaru, E. . (2012). AN ASSESSMENT OF THE KENYAN COASTAL ARTISANAL FISHERY AND. Thesis Submittrd in Fulfillment of the Requirements for Degree of Master Science of Rhodhes University, (December).

[22] Mwaijande, F, A\&Lugendo, F. (2013). Journal of Rural and Community Development. Journal of Rural and Community Development, 10(2), 47-62.

[23] Mwangi, M. (2008). Aquaculture in Kenya; Status, challenges and opportunities.

[24] Obiero, K. O., Opiyo, M. a, Munguti, J. M., Orina, P. S., Kyule, D., Yongo, E., ... Charo-karisa, H. (2014). Consumer preference and marketing of farmed Nile Tilapia ( Oreochromis niloticus ) and African Catfish ( Clarias gariepinus ) in Kenya : Case Study of Kirinyaga and Vihiga Counties. International Journal of Fisheries and Aquatic Studies, 1(5), 67-76.

[25] Odaba, E. (2014). CHALLENGES OF DOING BUSINESS IN KENYA FROM A FINNISH PERCEPTIVE. Bachelor Thesis Degree Programme Internattional Business General Management, 58.

[26] Ogello, E. O., Obiero, K., \& Munguti, J. M. (2013). Lake Victoria and the Common Property Debate: Is the Tragedy of the Commons a Threat To Its Future ?, 7(2), 101-126.

[27] Okwu, O. J., Yahaya, M. A., \& Obinne, C. P. O. (2011). Analysis of Artisanal Fisher Folk Information Needs and Accessibility in Benue State, Nigeria. Asian Journal of Agricultural Sciences, 3(5), 408-413.

[28] Olale, E., \& Henson, S. (2013). The impact of income diversification among fishing communities in Western Kenya. Food Policy, 43, 90-99. http://doi.org/10.1016/j.foodpol.2013.08.008

[29] Oloo Rebecca Debora Atieno. (2011). Fish farming as a means of boosting the economy of Kisumu Fish farming as a means of boosting the economy of Kisumu County, Kenya, (December).

[30] Ondoro, C. O., \& Omena, D. (2012). Effect of Microfinance Services on the Financial Empowerment of Youth in Migori County, Kenya. Business and Management Review, 2(3), 22-35.

[31] Opondo, P, A. (2011). Fisheries and Fish traders of Lake victoria:Colonial policy and the development of fish production in Kenya,1880-1978. Thesis Submitted in Accordance with the Requirement for Degree of Doctor of Literature and Philosophy in the Subject History at the University of South Africa, (February), 2204-2204.

[32] Osondu, C. K. (2014). Analysis of profitability and production determinants of fish farming in Umuahia Capital Territory of Abia State , Nigeria. World Journal of Agricultural Sciences, 2(November), 168-176.

[33]Pike, R., Neale, B., \& Linsley, P. M. (2012). Corporate finance and investment - decisions and strategies. Retrieved from http://eprints.whiterose.ac.uk/74291/

[34] Raburu, P, O., Okeyo-Owuor, J, B., \& Kwena., F. (2012). Community Based Approach to the Management of Nyando Wetland, Lake Victoria Basin, Kenya, 157.

[35] Ruddle, K. (2011). "Informal" Credit Systems in Fishing Communities: Issues and Examples from Vietnam. Human Organization, 70(3), 224-232. http://doi.org/10.17730/humo.70.3.v4810k37717h9g01
[36] Thompson, O, A \& Mafimisebi, T, E. (2014). Fisheries and Aquaculture Profitability of Selected Ventures in Catfish Aquaculture in Ondo State , Nigeria. Fisheries and Aquaculture Journal, 5(2).

[37] Tryfos, P. (2001). Chapter 14: Factor analysis. Unknown.

[38] Twesigye, C. K. (2011). The Impact of Land Use Activities on Vegetation Cover and Water Quality in the Lake Victoria Watershed. The Open Environmental Engineering Journal, 4(1), 66-77. http://doi.org/10.2174/1874829501104010066

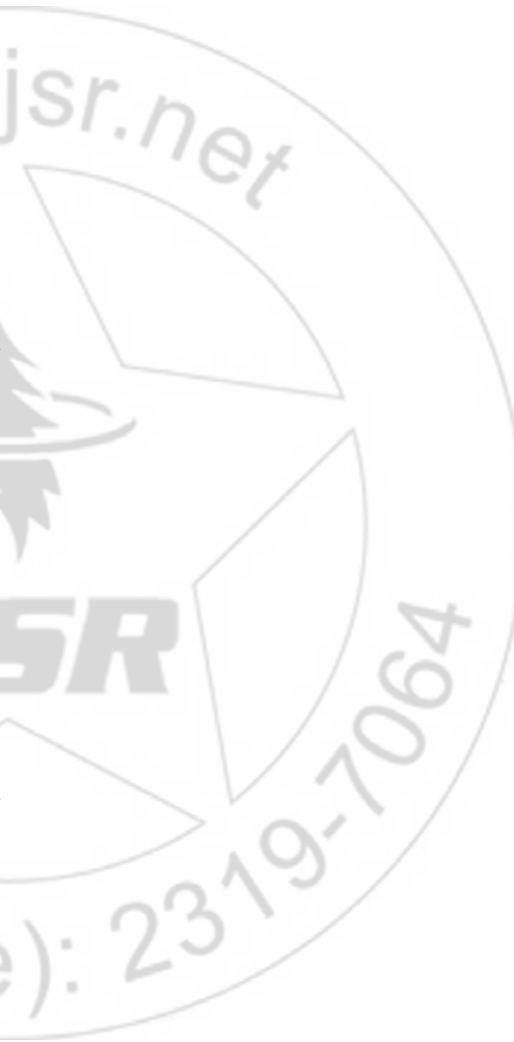

